\title{
Don't take the High Road: Tartanry and its Critics
}

David Goldie

If you were of a religious persuasion and had a sense of humour you might think tartan to be one of God's better jokes. To match up this gaudy, artificial, eyestrainingly irrational fabric with a countryside characterised by its mists and rains and a correspondingly rather dour people known throughout the world for canniness, pragmatism, and rationality, seems a rather sublime piece of audacity and one that can hardly be explained by the normal historical means. It's true that there may be material historical reasons for tartan, that an impoverished people might weave a kind of textile bricolage from whatever stray fibres might come to hand, for example, and it's also plausible that muted tartans might have a practical role as an effective camouflage. But this is still quite far from explaining how a piece of such abstract and unwarranted extravagance as 'Ye principal clovris of ye clanne Stewart tartan' might have come into being. ${ }^{1}$

In a similar vein it's entirely credible to argue that the heady collision of Sir Walter Scott, King George IV, and European Romanticism in Edinburgh in 1822 explains much about tartanry's sentimental vulgarity and its weird mixture of ostentation and supplication. But what remains seemingly beyond the range of explication (and what Scott already sensed in his fiction) is the fundamental, almost ridiculous mismatch between this impractical concoction and its symbolic importance to a nation seeking to build an international reputation on its hard practical skills in engineering, industrial chemistry, and finance. It might be said that this strange, gauche inappropriateness of tartan is a symptom of Scotland's

\footnotetext{
${ }^{1}$ A designation offered by the Sobieski Stuarts in Vestiarium Scoticum (1842).
} 
long-term inability to reconcile its highland and lowland cultures, or its rural and urban divisions. But such explanations fail to explain the extent to which tartan is and always was effectively a product of urbanism and lowlandism - if not in its actual invention then certainly in its definition and exploitation - and that the three groups who appear to have invested the most sentimental capital in it over the last century have been tourists, expatriates, and the urban proletariat. $^{2}$

At these and several other levels tartanry has offered a real difficulty for high-minded Scottish critics. For twentieth-century critics especially, who sought to engineer social and cultural change, whether through the politics of the left or of nationalism, the discourse of tartan, with its connotations of couthy sentimentalism and provincialism on the one hand and low-brow music-hall innuendo on the other, proved to be an aggravation and even a source of deep shame.

This, arguably, had been less of a problem in the nineteenth century, in spite of Balmorality and the vagaries of Victorian bourgeois taste that pushed tartan forcefully into the public gaze. The strength of the union and, perhaps, a culture of deference meant that tartan had few ostensible negative connotations and tended to be celebrated rather than derided as a symbol of national Scottish and imperial British pride. The kilt might not be much worn but it was widely respected, not least as the identifier of the highland soldier - a figure who loomed large in the Victorian popular imagination in a variety of guises, from the written accounts in the works of James Grant and the visualised heroics of Robert Gibb's 'The Thin Red Line' (1881) and Lady Butler's 'Scotland for Ever!'

\footnotetext{
${ }^{2}$ David McCrone, Understanding Scotland: The Sociology of a Stateless Nation (London \& New York: Routledge, 1996), 184.
} 
(1881) to the pathos of Philip Richard Morris's 'The Highland Laddie's Return' (1881).

That this view changed in the twentieth century was perhaps due to the development in the years surrounding the First World War of what we now recognise as the modern mass media: the large-circulation popular newspapers that followed the Daily Mail after 1896; a Music Hall transformed in the Edwardian era from marginal disrespectability to esteem and high popularity; and the newest and most truly international medium, the cinema, which spread like a flu across the civilized world in the twenty years following its invention.

These media in their very nature both threatened Scottish identity, by superseding the local networks through which regional and national cultural traditions had been formed, and offered it a hitherto unimaginably large arena in which it might be expressed. Cultural products like tartan now had a wider geographical space in which they might be seen and also, with the appearance of the relatively affluent working-class consumer, a greater social depth to their consumption - offering greater reach but to an arguably less discerning and discriminating audience. This, in a literal sense, vulgarised tartan. Now used as a brand to identify 'Scottishness', whether to promote loyalty within indigenous consumers in the ways exploited by the publications of the Thomson-Leng group or to signal romantic adventure to an international audience in Hollywood film, tartan had, in its mass-mediation, undergone a change - the line that might previously have separated tartan from tartanry had dissolved. ${ }^{3}$ All, it seemed, was now tartanry.

\footnotetext{
${ }^{3}$ David McCrone, Angela Morris, and Richard Kiely, Scotland the Brand: The Making of Scottish Heritage (Edinburgh: Edinburgh University Press, 1995).
} 
This was perhaps most evident in cinema, where tartan had been visible almost from the moment of the medium's inception. Some of the earliest Scottish films, such as The Gordon Highlanders Leaving Maryhill Barracks screened at the Glasgow Skating Palace by Arthur Hubner in 1897 and William Walker's 1898 Braemar Gathering at Balmoral, featured tartan subjects, chosen presumably for their visual interest, as had one of the first experimental films in the British Kinemacolor process, Tartans of the Scottish Clans (1906). ${ }^{4}$ Other early Scottishmade films drew not only on tartan's visual appeal but also on its connection to the romance traditions of highland fiction, among them Britain's first three-reel feature film, United Films' Glasgow-made Rob Roy (1906). ${ }^{5}$ International filmmakers were similarly quick to see the romantic appeal of Scott's tartanry, with two more adaptations of Rob Roy, one English and one American, before the First World War. This period also saw an American Lochinvar, Kenilworth, and Bride of Lammermoor in 1909; another American Lochinvar in 1911 and Lady of the Lake in 1913; and in 1914 an American and an English Heart of Midlothian (the American titled A Woman's Triumph) and another Bride of Lammermoor. The story of Mary Queen of Scots had been of particular interest to French filmmakers, who had produced seven separate versions before 1914. Macbeth was another favourite for international film-makers, with an American version in 1908, an Italian in 1909, a French in 1910, an English in 1911, and a German in 1914. There had even been an American Scotland Forever in $1913 .{ }^{6}$ The earlycinematic representation of Scotland, then, tended inevitably towards a tartan-

\footnotetext{
${ }^{4}$ Bruce Peter, 100 Years of Glasgow's Amazing Cinemas (Edinburgh: Polygon, 1996), 3.

${ }^{5}$ David Cloy, Scotland in Silent Cinema: A Commemorative Catalogue to Accompany the Scottish Reels Programme at the Pordenone Silent Film Festival, Italy 1998, ed. Janet McBain (Glasgow: Scottish Screen, 1998), 7. The only other feature produced in Scotland before the war was Inverness photographer Andrew Patterson's amateur film Mairi - The Romance of a Highland Maiden of 1913. ${ }^{6}$ See the filmography in Ibid., 14-18..
} 
draped vision of misty lochs and turbulent romance familiar to readers of nineteenth-century historical fiction, albeit interspersed with occasional comic representations of the highlander in short films such as The Adventures of Sandy MacGregor, 1904, McNab's Visit to London, 1905, and Sandy's New Kilt, 1914. The power of such highland romance to draw both audiences and the emerging stars of Hollywood can be seen in the decision taken by America's Sweetheart', the Canadian Mary Pickford, to expand her reputation for cutesy tempestuousness by taking on the role of Marget MacTavish, a chieftan's headstrong daughter, in The Pride of the Clan (1917).

If there was one home-grown figure who could be said to epitomise the kind of vulgar tartanry thrown up in this period it would almost certainly be Harry Lauder, the popular entertainer who for many years was Scotland's most visible embodiment on the world's stage: a kilted buffoon propped unsteadily on a ridiculously rustic walking stick, apt to dispense sly humour and easy sentiment to the tune of a cheery, well-sung song. Lauder was plainly never afraid of wrapping himself up in tartan for comic or sentimental effect, and was not averse either to exploiting it for more serious, if equally questionable, ends not the least of which was making substantial sums of money for himself. Lauder is a pivotal figure, not just for his notorious caricatures of Scottishness, but because of the role he played in enlisting tartan to the allied effort in the First World War. He worked tirelessly throughout the war, drawing on his wide range of dramatic skills and on the recognition of his jaunty highland image to entertain and cajole his audiences for the purposes of recruitment, troop 
entertainment, and charitable fund raising. ${ }^{7}$ He would gain a knighthood for this service in 1919, but in the eyes of some, he would win this by debauching the currency of Scottish culture, cheapening Scotland's markers of national identity and its martial tradition and letting them go for a sentimental song.

Lauder was not an original. 'Scotch comics' like W. F. Frame had helped establish the genre from which Lauder would never deviate very far (although he had, in fact, begun as an Irish comic). ${ }^{8}$ And music-hall jingoism was hardly new there had often been a noticeable connection between Scotch music-hall comedy and the wider imperial mission. ${ }^{9}$ Though the Scots martial tradition could sometimes be parodied, too as it was by the Scotch comic Harry Linn in his most celebrated number, 'The Fattest Man in the Forty-Twa', sung as he capered about in the costume of the $42^{\text {nd }}$ Highland Regiment. ${ }^{10}$ But Lauder's war efforts were particularly visible, caused at least partly by his promotion of the 'Harry Lauder Million Pound Fund' for wounded servicemen.

The popular-cultural context in which he was working during wartime was one that was particularly well-disposed towards tartan. A series of early-war two-reelers, among them Barker's A Daughter of Belgium (Oct. 1914), Crusade's A Daughter of France, Barker's Bravo Kilties!, and Samuelson's A Son of France (all Nov. 1914) had highland soldiers playing the role customarily associated in cinema with the Seventh Cavalry: that of coming to the rescue of civilians

\footnotetext{
${ }^{7}$ See Harry Lauder, A Minstrel in France (New York: Hearst's International Library, 1918).

${ }^{8}$ Alasdair Cameron and Adrienne Scullion, "W. F. Frame and the Scottish Popular Theatre Tradition," in Scottish Popular Theatre and Entertainment: Historical and Critical Approaches to Theatre and Film in Scotland, ed. Alasdair Cameron and Adrienne Scullion (Glasgow: Glasgow University Library, 1996), 39-61.

${ }^{9}$ Penny Summerfield, "Patriotism and Empire: Music-Hall Entertainment 1870-1914," in Imperialism and Popular Culture, ed. John M. MacKenzie (Manchester: Manchester University Press, 1986), Paul Maloney, Scotland and the Music Hall, 1850-1914 (Manchester \& New York: Manchester University Press, 2003), 18-20.

${ }^{10}$ Jack House, Music Hall Memories (Glasgow: Richard Drew, 1986), 15-16.
} 
imperilled by the depredations of marauding savages - in this case, those of the German military. Subsequent films, among them the Barker two-reeler, 24 Carat (1914), the comedy, Pimple in the Kilties (Jan. 1915), and Maurice Sandground's Kilties Three: A Scottish Romance of the Great War (1918), continued in this manner to portray the kilted soldier as a sentimentalised guarantor of British social stability.

When Lauder was performing in the revue Three Cheers in London's Shaftesbury Theatre in 1916-17, then, he pulled all the strings of Caledonian sentimentalism and brought the house down by singing 'The Laddies Who Fought and Won' as uniformed members of the Scots Guards marched on to the stage behind him. ${ }^{11}$. This was much remarked upon at the time, but was, again, not unique. The revue Razzle-Dazzle at Drury Lane in 1916, for example, closed its first half with a 'Scotland For Ever' extravaganza that featured three hundred chorus girls in a chaotic variety of tartans leading a band of marching pipers down the representation of a highland glen: not the most aesthetically tasteful way to celebrate Scottish martial achievement but it did affirm, as one commentator put it, 'the process by which an old feudal enemy had been claimed for the cause through those ever-popular Highland regiments' ${ }^{12}$

In the years after the war such facile sentiments began to ring a little hollow. As wartime idealism turned to post-war disenchantment the wartime cooption of tartan came to seem like a trick, perhaps a grim joke played on a nation that had lost a higher proportion of its fighting men than almost all of the nations

\footnotetext{
${ }^{11}$ See Lauder, A Minstrel in France, 84-9.

${ }^{12}$ Gordon Williams, British Theatre in the Great War: A Revaluation (London: Continuum, 2003), 47.
} 
that had contested the war. ${ }^{13}$ For the many people who saw things this way Lauder, as a visible symbol of this co-option, was particularly reviled. It comes as no surprise, then, to find the writers of the post-war Scottish Renaissance taking an active antipathy to everything that Lauder and his kilt appeared to stand for. In the eyes of the movement's driving force, and a man who had served in the war, Hugh MacDiarmid, tartanry joined the Burns cult and the literature of the Kailyard as pernicious expressions of a bastardised, inauthentic Scotland. MacDiarmid railed against Lauder frequently and vociferously, talking for example in 'The Scottish Muse' of 'the false trail of the Kailyard and Harry Lauder school' which 'demonstrably falsify and cheapen' the Scottish psychology, and the ways in which Scottish 'robustness and recklessness' are 'travestied into canniness and sickly sentiment' by popular literature and music-hall tartanry. ${ }^{14}$

MacDiarmid, as his nom de plume indicates, was a lowlander with an appreciation of the allure of the Celtic highlands. Born and brought up much closer to Sunderland than Sutherland, his attempts to found a revived Scottish culture often drew substantially on a highland cultural tradition to which he was alien by formation, and promoted a language, Gaelic, that he didn't speak. On the one hand his efforts in this direction are plainly a generous gesture that seek to construct an inclusive new national culture, but on the other they suggests that MacDiarmid was perhaps as susceptible as other more credulously romantic souls to the highland idea. He was ashamed of tartanry but himself wore the kilt, as if a careful line might be drawn between a purposive and a trivial use of

\footnotetext{
${ }^{13}$ The only nation to suffer a higher proportion of casualties was Serbia. See Niall Ferguson, The Pity of War (London: Penguin, 1998). See also C. E. Montague, Disenchantment (London: Chatto \& Windus, 1922).

${ }^{14}$ Hugh MacDiarmid, The Raucle Tongue: Hitherto Uncollected Prose, ed. Angus Calder, Glen Murray, and Alan Riach, 3 vols., vol. 1 (Manchester: Carcanet, 1996), 187.
} 
tartan. ${ }^{15}$ The argument for MacDiarmid was not about tartan itself, which he plainly considered an authentic or at least suitably pragmatic expression of nationhood, but of its vulgarisation in the hands of Harry Lauder, British imperialism, and American-led popular culture. ${ }^{16}$

Those who followed MacDiarmid later in the century in criticising tartanry, and in linking it with the kailyard as a twinned symbol of national degradation and false consciousness, were not on the whole kilt wearers and so did not need to respect the ambiguous spaces between tartan and tartanry. George Blake was concerned mainly with the way the kailyard had turned the focus of Scottish literature from the present to the past, and from the urban to the semi-rural, but could not resist seeing tartan as a malign ally in kailyard fiction's flight from realism. For Blake the Scottish novel's alternative modes of highland romance and lowland parochialism had made Scottish fiction evasive rather than engaged and had promoted 'a sort of national infantilism'.17

With the proliferation of tartan-tinged sentimentalism in mid-century, in the publications of D. C. Thomson and the frolics of Brigadoon and the White Heather Club, tartan and the kailyard increasingly seemed - at least to serious cultural commentators - to be not so much naïve ways of averting the public gaze from the real issues of the day as malign operators that monopolised the cultural infrastructure to the extent that alternative cultural discourse became

\footnotetext{
${ }^{15}$ See, for example, his comment to Sorley MacLean in a letter of 22 May 1936, that 'I've taken to regular kilt wearing', Dorian Grieve, Owen Dudley Edwards, and Alan Riach, eds., Hugh Macdiarmid: New Selected Letters (Manchester: Carcanet,2001), 112. William Burroughs would later describe MacDiarmid at the now notorious 1962 International Writers' Conference in Edinburgh 'stalking around in his kilt with his knobby blue knees saying that Burroughs and Trocchi belong in jail, not on a lecture platform, old jerk'. Allan Campbell and Tim Niel, eds., A Life in Pieces: Reflections on Alexander Trocchi (Edinburgh: Rebel Inc.,1997), 159.

${ }^{16}$ See David Goldie, "Hugh MacDiarmid, Harry Lauder, and Scottish Popular Culture," International Journal of Scottish Literature 1, no. 1 (2006).

${ }^{17}$ George Blake, Barrie and the Kailyard School (London: Arthur Barker, 1951), 9.
} 
impossible. This was the 'vast tartan monster' described with such a powerful mixture of gusto and disgust by Tom Nairn in The Break-Up of Britain, a devouring false consciousness that destabilised the Scottish psyche and reduced it not just to infantilism but to the point of neurosis. ${ }^{18}$ According to Nairn, 'vulgar tartanry' lay at the root of both kailyard's evasive nostalgia and what he described as 'cultural emigration'.19 Nairn was shrewd enough to acknowledge the difficulty of resisting tartan's popular pull as he attempted to push Scottish culture in another direction. 'Tartanry', he stated, 'will not wither away, if only because it possesses the force of its own vulgarity - immunity from doubt and higher culture. ${ }^{20}$ And he showed at least the beginning of a willingness to take it seriously as a source of real, as opposed to merely comic or trivial, disturbance in the Scottish mentality, arguing that if if 'the émigré-Kailyard dilemma can be taken to represent the plight of the nation's Ego,' then tartanry in the form of 'the Scott Monument, Andy Stewart and the Sunday Post' [....] surely is the Id with which the intelligentsia has always had to wrestle'. ${ }^{21}$

Several of those who followed Nairn's lead were, however, less ready to treat tartanry as a proper subject for analysis, and chose instead to take the critical high road mapped out by MacDiarmid, adopting an attitude of de haut en bas and the weapons of ridicule. Nairn had noted in the argument quoted immediately above that tartan constituted 'a huge, virtually self-contained universe of Kitsch'. Barbara and Murray Grigor plainly agreed, and sought to expose that kitsch to mockery in their Scotch Myths exhibition in St Andrews and Edinburgh in 1981, which was followed up the next year by Murray Grigor's

\footnotetext{
${ }^{18}$ Tom Nairn, The Break-up of Britain, Second, Expanded ed. (London: New Left Books, 1981), 162.

${ }^{19}$ Ibid., 156.

${ }^{20}$ Ibid., 165.

${ }^{21}$ Ibid., 163.
} 
related Channel 4 film Scotch Myths, and his contribution 'From Scott-land to Disneyland' to Colin McArthur's book Scotch Reels. Grigor's approach here was primarily visual and not immediately analytical - the essay in McArthur's collection was a photomontage in the manner of John Berger's Ways of Seeing (1972). But the relentless concatenation of tartan images was, presumably, intended to be polemical, to invite mockery and perhaps shame that the Scots might allow themselves to be represented in this way. For people already suspicious of tartanry this was, one would guess, both hilarious and reinforcing. For those who weren't above that culture, however - the very many unreconstructed readers of highland romance and buyers of People's Friend calendars, those who innocently enjoyed Thingummyjig, or who spent their weekends in highland dancing or marching in pipe bands - the effect would presumably be quite different. These people might feel, with some justification, that their tastes and pleasures were being mocked by a self-appointed intelligentsia who might claim to speak for Scotland - whatever that might be but who certainly didn't speak for them.

This sense of superiorism, of a politicised intelligentsia primed on Gramsci and Althusser, confidently separating out the Scottish workerist sheep from the tartan goats is arguably what characterises many of the essays in Scotch Reels. There can be little doubt that the collection advances some thoughtful analysis of the limiting effects of both tartanry and kailyard, and that it convinces in its major argument that these two discourses alone cannot fulfil the representational needs of a modern nation. But what is much less convincing is the argument, carried on from MacDiarmid and Nairn, concerning what McArthur describes as 'the seriously stunting effects Tartanry and Kailyard have 
had on the emergence of alternative discourses more adequate to the task of dealing with the reality of Scottish life'.22 This argument, that two popularcultural modes can effectively corner a national market and make alternative forms of expression impossible, is in itself extremely limiting and, to this reader at least, quite unpersuasive. Not only does it fail to account for the fact that a book like Scotch Reels has appeared out of that culture, which perhaps rather negates its own arguments, but it is an argument that also immediately places itself outside or above that culture: put simply, Scotch Reels, doesn't represent a discussion within Scottish culture but rather a solution for Scottish culture made by an enlightened group who have managed to escape its clutches. It is, then, paradoxically akin to Tom Nairn's notion of 'cultural emigration' - effectively an émigré account of a native culture made by those who have managed to free themselves from it or otherwise opt out.

This sense, that Scotch Reels does not speak within the culture but rather down to it, is reinforced by the book's sometimes supercilious tone. McArthur talks semi-facetiously at one point in his essay 'Scotland and Cinema: The Iniquity of the Fathers' about Loch Lomond and all it stands for, 'represented on scores of unspeakable postcards, shortbread tins and table mats'. ${ }^{23}$ In the use of the word 'unspeakable' here McArthur arguably manifests an attitude that undoes much of his essay's good work in detailed ideological analysis. For all the essay's sophisticated dialectic this kind of crude value judgement resembles nothing so much as straightforward snobbery - the simple distaste of an elite for the questionable preferences of the vulgar. Where Nairn had recognised the

\footnotetext{
${ }^{22}$ Colin McArthur, ed. Scotch Reels: Scotland in Cinema and Television (London: British Film Institute, 1982), 3 .

${ }^{23}$ Ibid., 65.
} 
formidable power of vulgarity and had to that extent respected it, McArthur appears simply to dismiss it as that which can't be spoken of in polite company. Ridicule is a valuable weapon and McArthur, like Grigor, uses it effectively as a means to underline the sheer daftness and occasional cynicism of tartanry. But the question remains whether they have in fact chosen the best way to interrogate the phenomenon.

Many of tartanry's critics in the twentieth century appear often to have proceeded without a full awareness of the ironies they generated in that criticism. Hugh MacDiarmid in kilt ranting at Harry Lauder for his inauthenticity comes to seem like Caliban raging at his own image in the mirror; and then there is the émigré Tom Nairn skewering tartanry and kailyard as the fond products of distantiation and disengagement; the Grigors seeking to expose tartanry's Kitsch but reproducing it in their own form of critical Kitsch; and Colin McArthur employing the analytical tools of socialism to assert the superiority of his tastes over those of the generality. And all the while tartan has continued rejoicing on its way: the Edinburgh military tattoo is more popular than ever, having consistently since the millennium sold out all its tickets in advance, the Scottish National Party gives guarded but tacit support to Braveheartism, and Billy Connolly once the great hope of a vibrant cultural Clydesideism is now the laird of Candacraig House in Strathdon and presides, 'decked head to toe in tartan' according to the Press and Journal, over the Lonach Gathering and Highland Games. $^{24}$

\footnotetext{
${ }^{24}$ Press and Journal, 24 August 2009. For McArthur's hope that Connolly might become 'a major subversive, and therefore progressive, force in Scottish cultural life', see Scotch Reels, 64.
} 
This suggests that somehow these critics got it wrong about tartanry, that in dismissing it too easily they failed to understand its appeal and underestimated its continuing power. Had MacDiarmid and those critics who followed him shown a greater tolerance of tartanry, had they tried to understand a little more and condemn a little less, then they might have been able to enjoy a more productive relation with the phenomenon and with Scottish popular culture more generally. The faults of their critical approaches are arguably ones of perspective and can perhaps be described in a paradox - firstly, that they took tartan too seriously and secondly, that they didn't take it seriously enough.

The way in which tartan was taken too seriously might be seen in the claims that tartan and kailyard had driven more serious forms of national expression out of the market place. This was what MacDiarmid accused the 'over-paid clown' Lauder of doing in effectively taking the bread out of the mouths of more serious entertainers and cultural workers. ${ }^{25}$ This argument, that in promoting one very limited representation of Scotland Lauder was excluding all other views - that he was operating as a kind of cultural monopolist - surely overestimates his power. He was, after all, only a singer and popular entertainer working in a largely free cultural marketplace, which meant he earned only what the public chose to pay him out of their own pockets. One would surely have to have an extremely low opinion of either a nation or a popular audience to believe that it felt all its representational needs were exhausted by such a limited repertoire. All cultures have their Kitsch, but most are more relaxed in their attitudes towards it. Bollywood, for example, offers a version of Indian culture

\footnotetext{
${ }^{25}$ See 'Special Correspondent' [Hugh MacDiarmid], 'Scottish People and Scotch Comedians', Stewartry Observer, 23 August 1928, in The Raucle Tongue, vol. 2, 115.
} 
that is aesthetically dubious and perhaps even mildly embarrassing to some tastes, but it would be difficult to argue that it holds back other more serious representations of the nation or investment decisions in the Indian economy. In other words, it would be rare to find a serious person who thought any less of India because of it. Union Flag Kitsch - whether it's seen in Ginger Spice's dress, the roof of a Mini, or in souvenir shops the length of Oxford Street - similarly attracts interest and embodies what some might consider a questionable aesthetic but causes little real anguish or damage to the national self-image.

To that extent, then, perhaps cultural critics need simply to relax - to learn to stop worrying and love the bombast, the splendour, and the folly of tartan. In this way they might put themselves in a better position to focus on the things that actually matter in the national culture and let the inessentials go. But there are also more troubling questions about tartanry that might repay deeper thought, and might make it more than the simple joke with which this chapter began.

For example, is noticeable that few commentators other than Nairn have thought to interpret tartan as a manifestation of the Caledonian id - as an irrational technicoloured desire glimpsed momentarily and perhaps troublingly through the stifling hodden covers of the Scottish superego, like pink lace panties under a policeman's uniform. And that's because tartan (like a British policeman joke) is somehow always already below serious consideration. A joke to Freud was a means of venting the dark social-unacceptabilities of sex, but that road of possibility seems always closed off to tartanry, which appears to exist only in a world of couthy sentiment or in a Donald McGill universe of buffoonery and mildly smutty innuendo. The subject of what lies beneath the kilt has for years 
been a reliable source of humour and speculation for seaside postcards, bestman's speeches, and films like Carry on up the Khyber, but any attempt to analyse this further, to really look up the kilt and try to come to terms with exactly why it's considered so humorous and so embarrassing would, one guesses, only meet with more laughter or with hostility. Tartan provokes either a smile or a grimace; both are gestures that hold it at a distance.

This is unfortunate, because what is perhaps sometimes underestimated is the intrinsic value of some of the things that have come to us wrapped in tartan. Harry Lauder may seem merely laughable at this distance, as the chief of a clan of 'tartan-clad Liberaces whom Billy Connolly has described as "singing shortbread tins"', ${ }^{26}$ But to think in this way is to disregard the very many contemporary opinions that recognised him as a highly skilled performer. MacDiarmid might gibe that Lauder was a purveyor of 'hokum, hokum, hokum', but there were many more who were prepared to take him seriously as an entertainer and actor. ${ }^{27}$ Even when he was at his most mawkish there seems to have been, in some eyes at least, a saving quality in his performance that turned it into something very like art. This was certainly the case in the wartime performances of 'Laddies Who Fought and Won' at the Shaftesbury Theatre mentioned earlier. A reviewer in The Times who saw the show in early 1917 expressed his general belief that that 'patriotic songs sung by actors in khaki are detestable', but nonetheless saw something exceptional in Lauder's performance. Lauder was, he wrote, in his example of personal sacrifice and the intensity of his

\footnotetext{
${ }^{26}$ Michael Gardiner, Modern Scottish Culture (Edinburgh: Edinburgh University Press, 2005), 199.

${ }^{27}$ To Circumjack Cencrastus, Hugh MacDiarmid, Complete Poems, ed. Michael Grieve and W. R. Aitken, 2 vols., vol. 1 (Manchester: Carcanet, 1993), 252-4.
} 
performance, 'the very voice of all those' enduring life at the front. ${ }^{28} \mathrm{H}$. V. Morton took up a similar refrain when he insisted that 'Lauder's genius is a thing apart' and talked of finding 'something essentially honest, good, pure, and simple' in his performance. ${ }^{29}$ The great Times theatre critic James Agate discerned in Lauder 'an exceedingly fine feeling for character', and described him as a 'great actor', 'an evangelist whose tidings are of pure joy'.30 Even one of Lauder's harsher Scottish critics, George Blake, had to admit that Lauder in his heyday was 'inspired by at least near-genius'. ${ }^{31}$ So while MacDiarmid was content to see Lauder's performance as caricature and treat it as caricature, what he missed, and what audiences and many reputable theatre critics presumably didn't, was the operation within this tartanry of a more complex aesthetic quality and humanity.

It would, of course, be pushing it a little to say that all manifestations of tartanry can bear such scrutiny. There are plainly forms that most people would agree have very limited claim to serious aesthetic consideration. While there are occasions at which tartan is taken wholly seriously, as formal wear at weddings and funerals, for example, or in the performance of highland music, there are many more others in which it is consumed not quite as Kitsch but certainly with a degree of irony and self-reflexiveness in the form of a kind of guilty pleasure. An unsubtle critique of tartanry is one that fails to recognise that this is a fairly common and quite legitimate strategic use, and which fails to understand the complexity of this response. When Nairn talks of the 'vast tartan monster' he

\footnotetext{
${ }^{28}$ The Times, 4 January 1917, 11; quoted in Williams, British Theatre in the Great War, 32.

${ }^{29}$ H. V . Morton, In Search of Scotland (London: Methuen \& Co., 1929), 155-6.

${ }^{30}$ James Agate, Immoment Toys: A Survey of Light Entertainment on the London Stage, 1920-1943 (London: Jonathan Cape, 1945), 201-2.

${ }^{31}$ Blake, Barrie and the Kailyard School, 81.
} 
conjures an idea of tartanry as something along the lines of an Althusserian ideological state apparatus in which consumers of tartan are little more than interpellated subjects. Such a model offers no agency to the act of consumption itself, positing instead an individual who is made passive in the face of tartan's relentless hailing. ${ }^{32}$ The evidence suggests, however, that tartanry is often consumed and actively remade by otherwise autonomous individuals. This is unarguably the case of Caroline Sullivan, the rock critic of the Guardian. Sullivan, an American, was in her youth a fan of the Bay City Rollers, and she recounts in her memoir Bye Bye Baby: My Tragic Love Affair with the Bay City Rollers the ways in which she and her friends, the self-named 'Tacky Tartan Tarts', both revelled in and appropriated for themselves the group's shameless tartanry. The way Sullivan tells it this was not an act of submission to a dominant discourse, but rather a playful, reflexive act of affiliation and ultimately rejection that was made almost entirely on her own terms - an act of empowerment rather than one of subjection. For Sullivan, tartanry offered a ground on which she might express her emerging identity as a young adult rather than an ideological straitjacket that constricted and narrowed her growth. ${ }^{33}$ Craig Beveridge and Ronald Turnbull have written persuasively about the need to read popular culture, and particularly Scottish popular culture, in ways that recognise this mode of strategic, reflexive consumption. In their view, the criticism of tartanry has tended to

overlook, or ignore a major postulate of cultural analysis: that meanings are never passively consumed, but always subject to selection and

\footnotetext{
${ }^{32}$ See Louis Althusser, "Ideology and Ideological State Apparatuses," in Lenin and Philosophy and Other Essays (London: NLB, 1970).

${ }^{33}$ Caroline Sullivan, Bye Bye Baby: My Tragic Love Affair with the Bay City Rollers (London: Bloomsbury, 2000).
} 
adjustment to other discourses. There is reality, no Sunday Post reader waiting to soak up the messages conveyed by D. C. Thomson, but only Sunday Post readers, people who are also trade unionists, or Kirk-goers, or nationalists, or defenders of animal rights, and their response to tartanry is not uncritical assimilation but a complex negotiation dependent on the beliefs and values which are bound up with these other concerns. $^{34}$

This is surely the proper response towards tartanry. When Scotland's football fans, the so-called 'Tartan Army', pull on their jimmy wigs and drape themselves in lions rampant and outrageous tartans they are showing anyone with the eyes to see it a highly sophisticated idea of Scottishness that embodies both passion and humour - that signifies both a patriotic seriousness and generous expansive irony - they are flaunting the fact that they are not the victims of Scottish representational tradition but its masters. The problem with the higher critics of nationalism in the twentieth century was that they failed to see that in actively consuming and replicating tartanry in this way popular culture did not yield but effectively took ownership of it. This is a mistake that twenty-first-century criticism shouldn't and probably won't make. Tartanry is, and should be seen as something of a joke. But we should always remember that jokes are complex things, and remember too that you can do much more interesting things with jokes that simply laugh at them.

\footnotetext{
${ }^{34}$ Craig Beveridge and Ronald Turnbull, The Eclipse of Scottish Culture: Inferiorism and the Intellectuals (Edinburgh: Polygon, 1989), 14.
} 
Agate, James. Immoment Toys: A Survey of Light Entertainment on the London Stage, 1920-1943. London: Jonathan Cape, 1945.

Althusser, Louis. "Ideology and Ideological State Apparatuses." In Lenin and Philosophy and Other Essays, 127-86. London: NLB, 1970.

Beveridge, Craig, and Ronald Turnbull. The Eclipse of Scottish Culture: Inferiorism and the Intellectuals. Edinburgh: Polygon, 1989.

Blake, George. Barrie and the Kailyard School. London: Arthur Barker, 1951.

Cameron, Alasdair, and Adrienne Scullion. "W. F. Frame and the Scottish Popular Theatre Tradition." In Scottish Popular Theatre and Entertainment: Historical and Critical Approaches to Theatre and Film in Scotland, edited by Alasdair Cameron and Adrienne Scullion, 39-61. Glasgow: Glasgow University Library, 1996.

Campbell, Allan, and Tim Niel, eds. A Life in Pieces: Reflections on Alexander Trocchi. Edinburgh: Rebel Inc., 1997.

Cloy, David. Scotland in Silent Cinema: A Commemorative Catalogue to Accompany the Scottish Reels Programme at the Pordenone Silent Film Festival, Italy 1998. Edited by Janet McBain. Glasgow: Scottish Screen, 1998.

Ferguson, Niall. The Pity of War. London: Penguin, 1998.

Gardiner, Michael. Modern Scottish Culture. Edinburgh: Edinburgh University Press, 2005.

Goldie, David. "Hugh Macdiarmid, Harry Lauder, and Scottish Popular Culture." International Journal of Scottish Literature 1, no. 1 (2006).

Grieve, Dorian, Owen Dudley Edwards, and Alan Riach, eds. Hugh Macdiarmid: New Selected Letters. Manchester: Carcanet, 2001.

House, Jack. Music Hall Memories. Glasgow: Richard Drew, 1986.

Lauder, Harry. A Minstrel in France. New York: Hearst's International Library, 1918.

MacDiarmid, Hugh. Complete Poems. Edited by Michael Grieve and W. R. Aitken. 2 vols. Vol. 1. Manchester: Carcanet, 1993.

- - - The Raucle Tongue: Hitherto Uncollected Prose. Edited by Angus Calder, Glen Murray and Alan Riach. 3 vols. Vol. 1. Manchester: Carcanet, 1996.

Maloney, Paul. Scotland and the Music Hall, 1850-1914. Manchester \& New York: Manchester University Press, 2003.

McArthur, Colin, ed. Scotch Reels: Scotland in Cinema and Television. London: British Film Institute, 1982.

McCrone, David. Understanding Scotland: The Sociology of a Stateless Nation. London \& New York: Routledge, 1996.

McCrone, David, Angela Morris, and Richard Kiely. Scotland the Brand: The Making of Scottish Heritage. Edinburgh: Edinburgh University Press, 1995.

Montague, C. E. Disenchantment. London: Chatto \& Windus, 1922.

Morton, H. V. In Search of Scotland. London: Methuen \& Co., 1929.

Nairn, Tom. The Break-up of Britain. Second, Expanded ed. London: New Left Books, 1981.

Peter, Bruce. 100 Years of Glasgow's Amazing Cinemas. Edinburgh: Polygon, 1996. 
Sullivan, Caroline. Bye Bye Baby: My Tragic Love Affair with the Bay City Rollers. London: Bloomsbury, 2000.

Summerfield, Penny. "Patriotism and Empire: Music-Hall Entertainment 18701914." In Imperialism and Popular Culture, edited by John M. MacKenzie, 17-48. Manchester: Manchester University Press, 1986.

Williams, Gordon. British Theatre in the Great War: A Revaluation. London: Continuum, 2003. 